\title{
História do Pensamento Econômico
}

\author{
Título: História do Pensamento Econômico \\ Autor: Isaac Ilich Rubin \\ Edición: Editora UFRJ, Rio de Janeiro, 2014. 523 pp. \\ Tradução do inglês: Rubens Enderle \\ ISBN. 978-85-7108-366-0 \\ Leonardo GOMES DE DEUS \\ Universidade Federal de Minas Gerais
}

A recente publicação em português de um livro soviético de 1923 sobre história do pensamento econômico causa perplexidade à primeira vista. Tal edição, entretanto, é muito oportuna por três motivos. Em primeiro lugar, Isaac Rubin é um dos mais importantes intérpretes do pensamento marxiano em todo o século passado. Em segundo lugar, a leitura que realizou de Marx voltou a ser objeto de atenção graças às recentes edições de seus manuscritos que se julgavam perdidos, como os Estudos sobre a teoria do dinheiro de Marx (Argument Verlag, 2012). Finalmente, a história do pensamento econômico realizada por Rubin tem merecido nova avaliação a partir da publicação das obras completas de Marx e Engels (MEGA) desde a década de 1970, como bem aponta a excelente apresentação à edição brasileira. De fato, a obra de Rubin segue a perspectiva desenvolvida nas chamadas Teorias da Mais-Valia de Marx, como se sabe agora, uma obra editada por Karl Kautsky, em 1905, com algumas distorções. Esse fato, no entanto, em lugar de invalidar a abordagem de Rubin, antes torna mais destacadas as suas virtudes e sua importância para nosso tempo.

O texto de Rubin foge de dois perigos muito frequentes nas histórias do pensamento econômico. Por um lado, dentro do marxismo, escapa da abordagem do pensamento econômico como ideologia em sentido negativo, isto é, como conjunto de ideias de dominação de classe. Longe disso, Rubin mostra o enraizamento prático das ideias que expõe, mas não pretende estabelecer uma relação direta e esquemática entre infraestrutura e superestrutura ou entre consciência intelectual e classe social, por exemplo. Em última análise, sem ter conhecido a Ideologia Alemã, forneceu uma gênese histórica e social bastante adequada de cada autor que analisou sem fornecer uma identidade pedestre entre conjuntura histórica e produção intelectual, algo que lhe permite reconhecer a importância de vários indivíduos, como Hume, no desenvolvimento da ciência. Por outro lado e por essa razão, Rubin não incorreu no erro tão comum em nosso tempo de fazer uma história do pensamento econômico independente do mundo social, isto é, uma história das ideias que não forneça o seu lugar no mundo, a transmitir a leitores e estudantes a noção de uma acumulação de ideias em evolução a partir de sua própria lógica interna, a partir de mero exercício de retórica e convencimento.

A exposição de Isaac Rubin, diante disso, não segue aquela de Marx em sua literalidade, mas principalmente naquilo que tem de decisivo: situar o nascimento da ciência econômica próximo do nascimento da própria economia capitalista, quando os primeiros problemas econômicos puderam ser minimamente elevados ao pensamento abstrato. O livro começa com os problemas abordados pelos mercantilistas, quando a ciência econômica, antes de alcançar a perspectiva mais universal do século XVIII, devota-se "às específicas questões que haviam surgido com o desenvolvimento do capitalismo primitivo e que demandavam urgentemente uma solução prática” (p. 60). Rubin reconhece o caráter inovador de várias abordagens, mas também seus limites, algo que fará ainda a propósito de sua leitura da Fisiocracia, escola condenada ao fracasso em razão do atraso material do Antigo Regime. Essa escola, no entanto, foi a responsável definitiva pela elevação dos problemas econômicos às abstrações universais, isto é, a tentativa de "descobrir a conexão entre todos os fenômenos básicos da economia capitalista" (p. 187).

As duas primeiras partes do livro permitem a Rubin, em seguida, avaliar o itinerário da Economia Política Clássica, do nascimento à desintegração. Para Rubin, Smith representa a síntese crítica do percurso anterior, mas um grande avanço, graças "por um lado, à sua qualidade de 
generalização teórica e, por outro lado, à eloquência com a qual ele expôs as ideias do livrecomércio" (p. 210). Marxianamente, Rubin considera o livro de 1776 uma instauração do ponto de vista científico. Esse reconhecimento também é reservado a Ricardo, cujas pesquisas foram "realizadas com a mais extrema honestidade e probidade científica" (p. 290), isto é, tal como Marx, Rubin considera que Smith e Ricardo representam a ideologia positivamente determinada, isto é, a apreensão intelectual de um determinado modo de vida social, nem sempre idêntica, imediatamente, ao interesse de classe. A exposição que Rubin realiza desses autores pode ser lida ainda hoje com grande interesse, dado seu rigor sistemático e sua abrangência. Há que se observar, para tanto, que aquilo que denomina de "interesse de classe", "expressão clara" de "preocupações e exigências da burguesia" de modo algum indicam que não atribuísse, à nascente Economia Política Clássica, seu estatuto de cientificidade. Smith e Ricardo são a expressão intelectual do capitalismo industrial e os limites de seus pensamentos não são dados por questões intelectuais, mas pelas próprias contradições do nascente objeto que buscaram descrever.

A última parte da exposição segue as Teorias da Mais-Valia, sobre a desintegração da escola ricardiana. De particular interesse é a leitura -que Marx planejara nos Grundrisse, mas que não realizou- sobre John Stuart Mill, cuja obra "foi apenas o sinal de que a escola clássica estava em seus estágios finais de desintegração" (p. 435). Segundo Rubin, Mill representa a passagem da ciência econômica como teoria para mera filosofia social. A ciência econômica não era mais capaz de legitimar uma prática política progressista, portanto, tornou-se a defesa efetiva do statu quo.

Na conclusão, Rubin faz breve resumo da obra. Uma frase pode ser lida como advertência a historiadores e economistas: "A economia política burguesa tornou-se progressivamente apologética (passou a ter como objetivo a justificação do capitalismo) e vulgar (restringiu sua investigação ao estudo superficial dos fenômenos tal como eles aparecem para o capitalista, em vez de investigar as conexões internas entre eles)" (p. 458). Fornecer a gênese histórica e social das ideias econômicas é condição primeira para sua compreensão, requisito para a crítica dessas ideias ou prospecção de seu futuro. O livro de Rubin é, portanto, leitura recomendável. Que não se esperem muitos anos por outras traduções. 